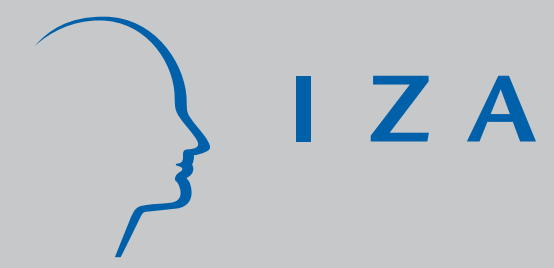

IZA DP No. 320

Strategic Hiring Behavior in Empirical Matching Functions

René Fahr

Uwe Sunde

J uly 2001 


\title{
Strategic Hiring Behavior in Empirical Matching Functions
}

\author{
René Fahr \\ IZA, Bonn and University of Bonn \\ Uwe Sunde \\ IZA, Bonn and University of Bonn
}
Discussion Paper No. 320 June 2001

\author{
IZA \\ P.O. Box 7240 \\ D-53072 Bonn \\ Germany \\ Tel.: +49-228-3894-0 \\ Fax: +49-228-3894-210 \\ Email: iza@iza.org
}

This Discussion Paper is issued within the framework of IZA's research area Mobility and Flexibility of Labor Markets. Any opinions expressed here are those of the author(s) and not those of the institute. Research disseminated by IZA may include views on policy, but the institute itself takes no institutional policy positions.

The Institute for the Study of Labor (IZA) in Bonn is a local and virtual international research center and a place of communication between science, politics and business. IZA is an independent, nonprofit limited liability company (Gesellschaft mit beschränkter Haftung) supported by the Deutsche Post AG. The center is associated with the University of Bonn and offers a stimulating research environment through its research networks, research support, and visitors and doctoral programs. IZA engages in (i) original and internationally competitive research in all fields of labor economics, (ii) development of policy concepts, and (iii) dissemination of research results and concepts to the interested public. The current research program deals with (1) mobility and flexibility of labor markets, (2) internationalization of labor markets and European integration, (3) the welfare state and labor markets, (4) labor markets in transition, (5) the future of work, (6) project evaluation and (7) general labor economics.

IZA Discussion Papers often represent preliminary work and are circulated to encourage discussion. Citation of such a paper should account for its provisional character. 
IZA Discussion Paper No. 320

June 2001

\section{ABSTRACT \\ Strategic Hiring Behavior in Empirical Matching Functions}

This paper makes two contributions to the empirical matching literature. First, a recent study by Anderson and Burgess (2000) testing for endogenous competition among job seekers in a matching frame-work, is replicated with a richer and more accurate data set for Germany. Their results are confirmed and found to be surprisingly robust. Second, the matching framework is augmented by endogenous strategic hiring behavior on the side of vacancyposting firms. Neglecting job competition, the relevance of strategic hiring is shown using the same empirical strategy. At the same time, the test is shown to be invalid if both types of endogenous behavior are present

JEL Codes: J41, J64

Keywords: Matching models, job search, vacancies, unemployment, job competition, strategic hiring

René Fahr

IZA

P.O. Box 7240

D-53072 Bonn

Germany

Tel.: +492283894533

Fax: +492283894510

Email: fahr@iza.org

\footnotetext{
* We are grateful to Christian Belzil, Hielke Buddelmeyer, Petra Todd and Stephen Trejo for very helpful comments. We thank Oliver Bruttel for assistance with the data. All remaining errors are our own. Financial support from DFG is gratefully acknowledged.
} 


\section{Introduction}

In a recent contribution, Anderson and Burgess (2000), henceforth AB, show that the results of empirical studies of matching functions must be interpreted with caution. In particular, they argue that what is commonly estimated as a matching function is in fact a reduced form combination of a structural matching model and a job competition model. Therefore, the estimated parameters are reduced form parameters instead of the structural parameters of the matching technology.

The matching function is a central tool in modern macroeconomic labor research. Essentially, it is a shortcut to describe the functioning of a labor market characterized by incomplete information and trading frictions. ${ }^{1}$ The matching function relates the number of active searchers on either side of the labor market (job seekers and vacancies to be filled) to the flow of new hires, thereby formalizing the view that matches do not arise immediately but involve active search on both sides.

Besides being the first to estimate matching functions using quarterly data at the level of U.S. states, the main innovation of AB lies in augmenting the matching approach with a model of endogenous job competition on the side of job searchers along the lines of Burgess (1993). Their presumption is that employed individuals increase their search intensity when they observe that the offer arrival rate increases, that is, when it becomes easier for them to get an offer from another firm. This behavior in turn changes the composition of the pool of job searchers. If it is assumed that employed applicants have an advantage of being accepted over nonemployed applicants (or at least no disadvantage), for example due to stigmatization of nonemployed job seekers, the share of job accessions by nonemployed relative to total hires will decrease. This in turn affects the interpretation of the parameters of a matching function estimated from using data on total hires, vacancies and unemployed. The effect becomes clear when the authors estimate matching functions separately by the source of the new hires, employed and nonemployed, and obtain parameters which differ significantly among each other and from the results obtained using pooled data.

Due to the fact that the intensity with which employed individuals search (or their proportion of the pool of employed) is not observable, it is not possible to directly test this job competition hypothesis. AB suggest an indirect

\footnotetext{
${ }^{1}$ See e.g. Pissarides (1985) for an early contribution and Pissarides (2000) and Petrongolo and Pissarides (2001) for extensive overviews over the theoretical and empirical literature.
} 
test of the hypothesis derived from the predictions of a simple theoretical model of job competition. The test heavily depends on the correct choice of instruments used. Using an extraordinarily rich and precise German data set, the test is replicated and the findings of $\mathrm{AB}$ can be confirmed.

The framework of $\mathrm{AB}$ is extended by incorporating endogenous (strategic) hiring behavior on the demand side of the labor market: Firms intensify their search when the perceived applicant arrival rate increases. Using an identical test, the data allow to provide evidence also for the relevance of endogenous strategic hiring behavior. However, the indirect test of $\mathrm{AB}$ is shown to be invalid when both types of endogenous behavior are present, because the instruments used do not fulfill the orthogonality conditions. Thus, in this paper the correct insight of $\mathrm{AB}$ is extended, namely that the parameter estimates of matching functions are reduced form combinations, now of a structural matching function, a job competition model and a strategic hiring model, which cannot easily be disentangled.

The following section introduces shortly the model and the testing strategy of AB. Section III augments the model by allowing for endogenous hiring and demonstrates the effects of this on the benchmark model. In section IV, a German panel data set at the occupational level is described. This data set is used to replicate the study of $\mathrm{AB}$ and to exemplify the effect of including hiring competition. Section V concludes.

\section{Matching and Job Competition}

In this section, a matching model incorporating job competition along the lines of $\mathrm{AB}$ is developed. At the heart of each matching model stands the matching function, which relates the flow of total hires $M$ to the stock of those actively seeking a job, $J$, and the stock of vacancies to be filled, $V$, such that

$$
M=M(J, V)
$$

with $\frac{\partial M}{\partial J}>0, \frac{\partial M}{\partial V}>0$, and $M(0, V)=M(J, 0)=0$. This flow can be decomposed by its sources, that is into flows from nonemployment, $X$ and employment, $Q$, into new employment relations:

$$
M=X+Q
$$


The stock of persons actively searching for a job are also either nonemployed, $U$, or employed, $L-U$, where $L$ is the labor force. However, of those employed only a fraction $\phi$ is actively searching, so $J=U+(L-U) \phi$. The idea behind endogenous job competition is that this fraction $\phi$ is determined endogenously and depends positively on the arrival rate of job offers $\theta=M / J$, rendering $J$ endogenous. Intuitively, employed individuals observe the labor market situation and when many job offers become available, e.g. during a boom of the economy, they find it profitable to search for a better job. This in turn has an externality on those already looking for a job in that the probability of finding a job decreases for each individual. In the simplest case, the probability of receiving a job is the same for employed and nonemployed job searchers. Using these facts, the competition between nonemployed and employed job searchers is parameterized as the share of job accessions won by nonemployed, $\beta=X / M$. Solving for $\theta=\theta(M, U)$, one can write with $\rho$ being the relative offer acceptance rates of the two groups:

$$
\beta=\frac{\theta(M, U) U \rho}{M} .
$$

AB show that the elasticities of $\beta$ with respect to $M$ and $U$ can be derived to be ${ }^{2}$

$$
\begin{gathered}
\epsilon_{\beta, M}=\epsilon_{\theta, M}-1<0, \\
\epsilon_{\beta, U}=\epsilon_{\theta, U}+1>0 .
\end{gathered}
$$

Consequently, these elasticities are estimated as a test of the job competition hypothesis using as a job-competition equation:

$$
\ln \beta=\alpha_{1} \ln M+\alpha_{2} \ln U+\nu
$$

leaving out their demographic variables, state dummies and trends for simplicity. Using the definition of $\beta$, this can be rewritten to:

$$
\ln X=\left(1+\alpha_{1}\right) \ln M+\alpha_{2} \ln U+\nu .
$$

It becomes clear that any positive shock in $\nu$ will increase $X$ as well as $M$ from (2). AB therefore instrument $M$ using $V$ in the form of a help wanted index, since because of (1) it satisfies the rank condition and is uncorrelated with the relative sizes of the hiring flows, $X$ and $Q$ (order condition). In a 2SLS procedure, $M$ is first regressed on $V$ :

\footnotetext{
${ }^{2}$ The authors also present a model in which employers have a marginal preference for employed over nonemployed applicants. In this case, it can be shown that $\epsilon_{\beta, U}=0$ in a behavioral sense.
} 


$$
M=V \delta+\zeta
$$

and the predicted values $\hat{M}=V \hat{\delta}$ are then used in the regression of X on the second stage:

$$
\ln X=\left(1+\alpha_{1}\right) \ln \hat{M}+\alpha_{2} \ln U+\nu .
$$

Estimating this job competition model, the authors find significant negative coefficients for the (instrumented) hires variable, and coefficients for the stock of job searchers which are not significantly different from zero. They conclude that the job competition model is supported by the data ${ }^{3}$ and therefore should not be neglected in the interpretation of results of empirical studies of matching functions.

\section{Endogenous Hiring Behavior}

Only allowing job seekers to adjust their behavior endogenously, as was done in the preceding section, treats the two sides of the labor market in an asymmetric way. It is therefore natural to allow also for endogenous hiring behavior on the side of firms. For comparability with AB, this behavior will also be called "hiring competition". It will become clear that the procedure described above heavily depends on the assumption that the stock of vacancies is exogenously given.

During all phases of the business cycle there is significant job destruction and creation (see e.g. Davis and Haltiwanger, 1992). On the one hand, firms try to replace workers who dropped out for various reasons, thereby creating a permanent pool of vacancies, most of them usually registered at employment agencies. On the other hand, firms have plans how to develop over time, e.g. to expand, to shrink or to alter their activities. While they more or less have to cope with the situation on the labor market in the former case, they can take labor market conditions into account explicitly in the timing and planning of more fundamental reorganizations.

Let the stock of vacancies to be filled, $V$, be composed of "replacement"vacancies, $R$, and "new" vacancies, $N$. If firms observe that the arrival rate of successful vacancy fillings, $\tau=M / V$, increases, it becomes easier and cheaper to pursue new ventures since the new jobs related to that can be

\footnotetext{
${ }^{3}$ In particular, the model in which employers have a marginal preference for employed over nonemployed job searchers.
} 
filled quicker. As a result, firms open more vacancies of the second type, $N=N(\tau){ }^{4}$ These might not even be registered, but firms may try to fill them using alternative channels, thus $N$ is (at least partly) unobserved. However, this endogenous search behavior leads to a measurement error in the instrument used for total hires in estimating equation (4) if the pool of vacancies is taken to be registered vacancies or proportional to that, since $V=R+N(\tau)$.

The literature on the hiring behavior of firms contains evidence that supports the assumption of endogenous recruitment behavior and intensity. Barron et al. (1985) conclude that it is employer search that leads to new employment rather than search of job seekers and emphasize that intensity of job search is the critical factor in creating new employment. Franz (1992) finds procyclical job posting behavior when registered vacancies are adjusted for labor office interventions. Belzil (2000) finds that while there is gross job creation over the entire business cycle, wages seem to be very sensitive to net job creation, especially for entrants, while wages are inelastic to replacement. Moreover, unemployment has a negative effect on entrants' wages. This suggests that it might be cheaper for firms to create new jobs when it is easier to fill them with applicants. There is evidence that firms make substantial use of informal networks for their recruiting, see Montgomery (1991), Sicilian (1995) and Calvo-Armengol and Zenou (2001) and the references therein. Results presented by van Ours (1995) suggest that, whilst unemployed job seekers mainly apply for registered vacancies, employed job seekers additionally use alternative information for vacancies, not only notifications at employment agencies. Job competition is then a consequence of the use of multiple channels on the side of firms to fill a given vacancy. Mumford and Smith (1999) find that survey based vacancy data are a better and richer measure for the actual stock of vacancies to be filled and contain registered vacancies as a subset.

Just as for flows of job seekers to employment, the flows of posted vacancies to successful hirings can be differentiated by source: Those flows resulting from replacement vacancies, $P$, and those resulting from new vacancies, $O$ :

$$
M=P+O .
$$

Similar to the share of accessions won by nonemployed jobseekers $\beta$ in the job competition model, one can infer the intensity of hiring competition

\footnotetext{
${ }^{4}$ More formally, by construction $0 \leq \tau \leq 1$, and it is assumed that $\partial N / \partial \tau \neq 0, \forall \tau$. The example given implies procyclical posting of new vacancies, that is a positive derivative, but for the sake of the argument the endogenous behavior could also be countercyclical, i.e. $\partial N / \partial \tau<0$.
} 
by the share of successful hirings obtained from replacement vacancies: ${ }^{5}$

$$
\gamma=\frac{P}{M}
$$

In analogy to equation(4), a hiring competition model could be estimated as:

$$
\ln \gamma=\alpha_{3} \ln M+\alpha_{4} \ln R+\mu .
$$

However, due to the endogeneity of the search intensity on both sides of the market, the test of the job competition model proposed by AB fails. Consider again the argument behind the estimation of the indicator of job competition $\beta$ in (4), rewritten in the form of flows from non-employment $X$ as in (5). Any positive shock to $\nu$ will increase $\ln X$ and due to equation (2) also the regressor. The solution of this endogeneity problem was to instrument $M$ using the stock of vacancies $V$, since it satisfies rank and order conditions and can therefore explain $M$ while being orthogonal to $\nu$. This orthogonality breaks down once hiring competition is allowed for. The reason for this is the increase in $M$, triggered by $\nu$, increases ceteris paribus the arrival rate of successful vacancy fillings $\tau$. This in turn intensifies the endogenous search intensity of firms, $N$. However, as a consequence $V$ increases, so the stock of vacancies is endogenous and correlated with $\nu$. Therefore, in a matching model with job and hiring competition, $V$ is not a valid instrument anymore. In fact, the weaker the endogeneity of hiring competition, that is the smaller $\partial N / \partial \tau$, the smaller the endogeneity bias arising from instrumenting $M$ with $V$.

In other words, in the approach taken in the last section, the structural parameters of the matching function $M=M(J, V)$ could not easily be estimated due to the endogeneity of $J$, but the effects of endogenous job competition could be discovered through the changes in the relative sizes of the flows from nonemployment and employment into new employment relationships. This was possible using $V$ as an instrument. In this section, both $J$ and $V$ are endogenous, not allowing a clean instrumenting as before. To show the relevance of this extension, formalized as the effects on $\gamma$, in the next section the incorrect practice of instrumentation is deliberately repeated the other way around: Assuming matching with endogenous hiring competition but without job competition. This is done mirror image like to the 2-step approach

\footnotetext{
${ }^{5}$ It can easily be shown that $\epsilon_{\gamma M}=\epsilon_{\tau M}-1$ while $\epsilon_{\tau M}=1-(M / V)(\partial N / \partial \tau)$. Since $(M / V)$ is always positive, this implies that $\epsilon_{\gamma M}<0 \Leftrightarrow(\partial N / \partial \tau)>0$ and $\epsilon_{\gamma M}>0 \Leftrightarrow$ $(\partial N / \partial \tau)<0$, that is the elasticity of $\gamma$ with respect to $M$ is negative for procyclical and positive for countercyclical strategic hiring.
} 
of the preceding section, instrumenting total matchings with the (assumedly exogeneous) stock of job searchers $U$ and estimating the counterpart of (7):

$$
\ln P=\left(1+\alpha_{3}\right) \ln \hat{M}+\alpha_{4} \ln R+\mu .
$$

Adopting the argument of AB, a negative impact of (instrumented) matchings on the share of successful hirings through registered vacancies, $\gamma$, would mean (procyclical) endogenous hiring competition.

\section{Empirical Findings}

\section{IV.A. Data}

The data used for the analysis below are yearly data on unemployment, vacancies, employment levels and flows from registered vacancies to employment for Western Germany. The data are from official labor statistics and disaggregated at occupational level. ${ }^{6}$ Moreover, contrary to AB also data on the pools of job seekers and vacancies are disaggregated. In contrast to the help-wanted index frequently used in U.S. studies, the vacancy measure provides detailed information about all vacancies registered at local employment offices. The data where originally disaggregated by 40 occupational groups. To make the analysis as comparable as possible to the empirical analysis in AB these observations were clustered in four broad occupational groups. ${ }^{7}$ The hirings are measured on the individual level and stem from an anonymized representative $1 \%$ sample of German social security records. The data are available for the years 1975-1995, but reports of flows from registered vacancies to employment on an occupational level start in 1980. Therefore the data set eventually contains information for the years 1980-1995 for 40 occupational groups.

The individual data include a firm identifier and information on the employment status. All in all the data allow to identify hirings from one year to another for each occupation by source of hiring. Specifically, hirings from out

\footnotetext{
${ }^{6}$ In our view, disaggregating by occupations is a more appropriate representation of the relevant labor markets for job seekers and vacancy posting firms than disaggregating by regions or industries.

${ }^{7}$ The appendix provides a detailed description of the data used in the analysis including a list of occupational groups.
} 
of the labor force, from unemployment, and from employment can be distinguished. To make the analysis comparable to AB hirings from unemployment and from out of the labor force are classified as hirings from nonemployment.

\section{IV.B. Results}

That hirings from the stock of nonemployed job seekers are only a fraction of total hires is a well documented fact. As can be inferred from Table 1 , the data used for this study reveal that, taken over all occupations and periods, $69 \%$ of new matches were generated by nonemployed job seekers. This number is very similar to the approximately $70 \%$ reported by $\mathrm{AB}$ for their data, and to those found in other studies for U.S. data cited in their article. In addition, the data set allows to directly observe the sources of new matches with respect to the labor demand side. Almost $57 \%$ of all new matches, pooled over occupations and time, were created through registered vacancies, but $48 \%$ came through non-registered vacancies. This is taken as a first indication for the relevance of distinguishing between the different pools of posted vacancies.

\section{[INSERT TABLES 1 AND 2 ABOUt HERE.]}

Table 2 presents the results replicating the investigation of $\mathrm{AB}$ with the data described above, namely estimating a specification of the job competition model like in equation (4). The models used are directly comparable to those estimated in the original contribution in terms of specification and instrumentation. Model (1) presents OLS results, in Model (2) hirings are instrumented using registered vacancies per occupation. In model (3), instruments are lagged by one period and in model (4) current as well as once and twice lagged vacancy rates for the respective occupation are used as instruments. All models are estimated including dummies for four broad occupational groups and a time trend. ${ }^{8}$ The results are qualitatively identical to those obtained by AB: Coefficients on log of new hires are insignificant in the OLS case and significant and negative in the 2SLS specifications, and thus lead to the conjecture that job competition is important.

In analogy to this approach, a hiring competition model in the specification of equation (10) is estimated with the same data and analogous instruments. The results of this exercise are presented in Table 3. Again, the models include dummies for four broad occupational groups and time trends. In all models, the coefficients on hirings are significant and negative,

\footnotetext{
${ }^{8}$ Including controls for GDP and GDP growth did not change the results.
} 
as should be expected if there is hiring competition on the side of firms. In order to check the robustness of the results, the same models are estimated with controls for all 40 occupational groups. As is shown in Table 4, the results concerning hiring competition are qualitatively unchanged with still significantly negative coefficients for new matches. Thus, using a mirror-image-like approach to the test for job competition proposed by Anderson and Burgess leads to the impression that also hiring competition is important. In fact the coefficients indicate that strategic hiring behavior might have an even larger impact on the matching outcomes than job competition. However, one has to bear in mind that the empirical strategies presented above are not valid once both job competition and strategic hiring are present at the same time.

\section{[INSERT TABles 3 AND 4 ABOUt HERE.]}

\section{Conclusion}

This paper extends the insight of Anderson and Burgess (2000) by augmenting a matching framework by a strategic hiring component. Replicating their empirical study in an analogous way for hiring competition suggests the importance of treating endogeneity of search behavior in a symmetric way for both sides of the matching market, instead of focusing only on the behavior of job seekers. This suggests two things, first that the empirical strategy to detect job competition as suggested by Anderson and Burgess is not quite correct in that vacancies are no valid instruments in the context of endogenous search behavior on both sides; second, that reduced form estimations are combinations of the structural matching relationship, job competition

and strategic hiring behavior. Incorporating these three blocks into one framework calls for future research. 


\section{References}

Anderson, Patricia and Simon Burgess, "Empirical Matching Functions: Estimation and Interpretation Using State-Level Data", Review of Economics and Statistics 82(1) (February 2000), 93-102.

Barron, John, John Bishop and William Dunkelberg, "Employer Search: The Interviewing and Hiring of New Employees", Review of Economics and Statistics 67(1) (February 1985), 43-52.

Belzil, Christian, "Job Creation and Job Destruction, Worker Reallocation, and Wages", Journal of Labor Economics 18 (April 2000), 183-203.

Bender, Stefan, Anette Haas and Christoph Klose, "IAB Employment Subsample 1975-1995: Opportunities for Analysis Provided by the Anonymised Subsample", IZA Discussion Paper 117 (February 2000).

Burgess, Simon, "A Model of Competition between Unemployed and Employed Job Searchers: An Application to the Unemployment Outflow Rate in Britain", Economic Journal 103 (September 1993), 1190-1204.

Calvo-Armengol, Antoni and Yves Zenou, "Job Matching, Social Network and Word-of-Mouth Communication", CEPR Discussion Paper 2797 (May 2001).

Davis, Steven and John Haltiwanger, "Gross Job Creation, Gross Job Destruction and Employment Reallocation", Quarterly Journal of Economics 107 (1992), 819-63.

Franz, Wolfgang, "The German Labour Market", in: F. Padoa-Schioppa (ed.): Mismatch and Labour Mobility (1991), Cambridge University Press, Cambridge.

Montgomery, James D., "Social Networks and Labor-Market Outcomes: Toward an Economic Analysis", American Economic Review 81(5) (December 1991), 1408-18.

Mumford, Karen and Peter N. Smith, "The Hiring Function Reconsidered: On Closing the Cycle", Oxford Bulletin of Economics and Statistics 61(3) (1999), 343-364. 
Petrongolo, Barbara and Christopher Pissarides, "Looking into the Black Box: A Survey of the Matching Function", Journal of Economic Literature (2001), forthcoming.

Pissarides, Christopher," Short-run Equilibrium Dynamics of Unemployment, Vacancies and Real Wages", American Economic Review 75 (September 1985), 676-690.

Pissarides, Christopher, Equilibrium Unemployment Theory, 2nd ed. (2000), MIT Press, Cambridge Massachusetts.

Sicilian, Paul, "Employer Search and Worker-Firm Match Quality", Quarterly Review of Economics and Finance 35 (1995), 515-532.

Van Ours, Jan, "An Empirical Note on Employed and Unemployed Job Search", Economics Letters 49 (1995), 447-452. 


\section{Data Appendix}

The data used for the empirical analysis are yearly data for Western Germany disaggregated into 40 occupational groups. They are reported in official labor statistics as published in the Amtliche Nachrichten der Bundesanstalt fuer Arbeit. In order to make the estimations comparable to the estimations in Anderson and Burgess (2000) the 40 occupational groups were combined into four broad occupational groups (see Table A1 for details). The data include information on unemployment, vacancies, employment levels as well as flows from registered vacancies to employment. The stock data are reported as measured on the 30th of September of each year as reference date. The flows from registered vacancies to employment are reported as the flows aggregated over one year. In order to reproduce the relevant stocks for job seekers and vacancies for the entire period, the stocks of occupational measures as reported on the reference date of each year are augmented by a correction factor. This factor is obtained by dividing the aggregate flows aggregated over an entire period by the stock of the aggregate measure at the reference date (30.09.). This practice is necessary due to the lack of detailed vacancy flows data on the disaggregate (occupational) level.

The hirings were constructed using an anonymized representative $1 \%$ sample of Western German social security records from the German Institute for Employment Research (IAB). The basis of the IAB employment subsample 1975-1995 is the integrated notifying procedure for health insurance, statutory pension scheme and unemployment insurance which is regulated through German legislation. The employment statistics include all employees obliged to pay social insurance contributions and covers about $80 \%$ of all employed persons in Western Germany. In total this data set includes 6,711,153 notifications of 483,327 Western Germans (calculated on the basis of final notifications) (cf. Bender et al., 2000). The data contain information on individual characteristics, as well as a firm identifier. They are supplemented by person-related information on periods in which the Federal Employment Service paid benefits like the status of the unemployed and the type of benefit payments. Information as the employment status and the firm identifier, which are part of the official social security payments notifying pro-

cedure, are reported without errors. Because the anonymization procedure leads to missings in the codings of occupations which are not found in the official statistics, only the relative hirings in the sub-sample are regarded as representative. In order to obtain absolute values the relative numbers of hirings for each occupations were multiplied by the respective occupational 
employment levels from aggregate labor statistics.

To keep the data comparable to the aggregated data from labor statistics we retain all observations from 1980 to 1995, with the exception of notifications for a second job, for the construction of total hirings per year. The individual data allow to trace the employment career of the individuals over the entire observation period. Specifically, it is possible to distinguish changes from out of the labor force into employment or registered unemployment, changes into and out of unemployment, as well as job changes. Transitions from unemployment into employment in a specific occupation were identified by the change in the variable denoting the employment status. For people not in the labor force the variable for the employment status is coded as missing. Accordingly, a change in the value of the variable for employment status from missing to employed denotes a transition from out of the labor force to employment. Changes from employment to employment are identified by changes in the firm identifier. For the purpose of the empirical analysis of this paper the hirings from out of the labor force and from unemployment were summarized as hirings from nonemployment. The hirings for a specific occupation for a specific year were calculated by comparing all employees at the 30th of September of each year in a specific occupation and with a specific firm identifier to the values of these variables at the previous reference date. A problem of this procedure is that one misses short employment spells which take place within the year. The 30th of September was chosen to make the hirings information comparable to the data on the occupational level. 


\section{TABLE 1: STRUCTURE OF TOTAL HIRINGS WITH RESPECT TO SOURCE*}

Over all occupations (1980-1995)

hirings from nonemployment

hirings from employment

Over all occupations (1980-1995)
Share on total hires

$69 \%$

$31 \%$

Share on total hires

flows from registered vacancies $\quad 56.92 \%$

flows from non-registered vacancies $\quad 43.08 \%$

* Transitions calculated from individual West-German social security records. For details see data appendix.

TABLE 2: ESTIMATED MODElS OF JOB COMPETITION

\begin{tabular}{lcccc}
\hline $\begin{array}{l}\text { Dependent Variable: Log Share of Occupational Group Level Matches } \\
\text { from Nonemployed }\end{array}$ \\
& OLS & In $\beta$ ) & & \\
\hline & $(1)$ & $(2)$ & $(3)$ & $(4)$ \\
\hline Log of new hires in the & 0.006 & -0.096 & -0.094 & -0.098 \\
occupation & $(0.005)$ & $(0.012)$ & $(0.012)$ & $(0.012)$ \\
Log of occupational & 0.110 & 0.066 & 0.059 & 0.058 \\
unemployment rate & $(0.014)$ & $(0.017)$ & $(0.017)$ & $(0.018)$ \\
$\mathrm{R}^{2}$ & 0.2598 & - & - & - \\
Observations & 640 & 640 & 600 & 560 \\
\hline$*$ Robust standard errors are in parentheses. All models include occupation dummies for four \\
broad occupational groups and time trends. Instrument for new hires in model (2) is the log \\
vacancy rate in the respective occupation. Instrument in model (3) is the log occupational vacancy \\
rate lagged by one period. Instruments in model (4) are current log occupational vacancy rate and \\
log occupational vacancy rates lagged by one and two periods.
\end{tabular}




\section{TAble 3: Estimated MOdels OF HiRing COMPETITION}

\begin{tabular}{lcccc}
\hline $\begin{array}{r}\text { Dependent Variable: Log Share of Occupational Group Level Matches } \\
\text { from Registered Vacancies (ln } \gamma)^{*}\end{array}$ \\
\hline & OLS & 2SLS & 2SLS & 2SLS \\
& $(5)$ & $(6)$ & $(7)$ & $(8)$ \\
\hline Log of new hires in the & -0.067 & -4.592 & -6.538 & -1.325 \\
occupation & $(0.044)$ & $(1.609)$ & $(3.302)$ & $(0.445)$ \\
Log of registered vacancies in & 0.080 & -1.914 & -2.726 & -0.451 \\
the occupation & $(0.034)$ & $(0.719)$ & $(1.443)$ & $(0.196)$ \\
$\mathrm{R}^{2}$ & 0.1438 & - & - & - \\
Observations & 640 & 640 & 600 & 560 \\
\hline * Robust standard errors are in parentheses. All models include occupation dummies for four \\
broad occupational groups and time trends. Instrument for new hires in model (6) is the log \\
unemployment rate in the respective occupation. Instrument in model (7) is the log occupational \\
unemployment rate lagged by one period. Instruments in model (8) are current log occupational \\
unemployment rate and log occupational unemployment rates lagged by one and two periods.
\end{tabular}

\section{TAble 4: Estimated Models Of HiRING COMPETITION WITH DUMMIES FOR ALL OCCUPATIONAL GROUPS}

\begin{tabular}{|c|c|c|c|c|}
\hline \multicolumn{5}{|c|}{$\begin{array}{c}\text { Dependent Variable: Log Share of Occupational Group Level Matches } \\
\text { from Registered Vacancies }(\ln \gamma)^{*}\end{array}$} \\
\hline & $\begin{array}{c}\text { OLS } \\
(9)\end{array}$ & $\begin{array}{c}\text { 2SLS } \\
(10)\end{array}$ & $\begin{array}{c}\text { 2SLS } \\
(11)\end{array}$ & $\begin{array}{c}\text { 2SLS } \\
(12)\end{array}$ \\
\hline Log of new hires in the & -0.177 & -0.668 & -0.744 & -0.544 \\
\hline occupation & $(0.047)$ & $(0.126)$ & $(0.163)$ & $(0.122)$ \\
\hline Log of registered vacancies in & 0.209 & 0.214 & 0.189 & 0.1928 \\
\hline the occupation & $(0.026)$ & $(0.024)$ & $(0.026)$ & $(0.025)$ \\
\hline $\mathrm{R}^{2}$ & 0.951 & - & - & - \\
\hline Observations & 640 & 640 & 600 & 560 \\
\hline
\end{tabular}


TABLE A1: OCCUPATIONAL GROUP DEFINITIONS

\begin{tabular}{|c|c|c|}
\hline Occupation & $\begin{array}{c}\text { Occupational codes } \\
\text { (from official } \\
\text { statistics) }\end{array}$ & $\begin{array}{c}\text { Broad } \\
\text { occupational } \\
\text { groups* }\end{array}$ \\
\hline $\begin{array}{l}\text { plant cultivator, stockbreeding professions, } \\
\text { fishers }\end{array}$ & $01-05$ & 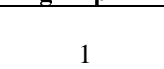 \\
\hline foresters and huntsmen & 06 & 1 \\
\hline miners and exhausters of mineral resources & $07-09$ & 1 \\
\hline $\begin{array}{l}\text { stone processors, producers of building } \\
\text { materials }\end{array}$ & $10-11$ & 1 \\
\hline ceramicist, glazier & $12-13$ & 1 \\
\hline chemical worker, polymer processor & 14-15 & 1 \\
\hline paper producer & 16 & 1 \\
\hline printer & 17 & 1 \\
\hline woodworker, wood processor & 18 & 1 \\
\hline metal worker & $19-24$ & 1 \\
\hline locksmiths, mechanics & $25-30$ & 2 \\
\hline electricians & 31 & 2 \\
\hline assemblers and metal related professions & 32 & 2 \\
\hline textile related professions & $33-36$ & 2 \\
\hline leather and fur manufacturers & 37 & 2 \\
\hline nutrition related professions & $39-43$ & 2 \\
\hline construction related professions & $44-47$ & 2 \\
\hline interior designers, furniture supplier, upholsterer & $48-49$ & 2 \\
\hline carpenters, modelers & 50 & 2 \\
\hline painters, varnishers and related professions & 51 & 2 \\
\hline goods tester, consignment professions & 52 & 4 \\
\hline unskilled workers & 53 & 4 \\
\hline machinists and related professions & 54 & 4 \\
\hline engineers, chemists, physicists, mathematicians & $60-61$ & 3 \\
\hline technicians & 62 & 3 \\
\hline technical specialists & 63 & 3 \\
\hline merchandise managers & 68 & 3 \\
\hline service merchants & $69-70$ & 3 \\
\hline transportation related professions & $71-73$ & 4 \\
\hline storekeepers, workers in storage and transport & 74 & 4 \\
\hline organization-,management-, office professions. & $75-78$ & 3 \\
\hline security service related professions & $79-81$ & 4 \\
\hline publicists, translators, librarians & 82 & 3 \\
\hline artists and related professions & 83 & 3 \\
\hline health care related professions & $84-85$ & 3 \\
\hline social work, pedagogy, science careers & $86-89$ & 3 \\
\hline beauty culture & 90 & 4 \\
\hline guest assistants, stewards, barkeepers & 91 & 4 \\
\hline domestic economy, housekeeping & 92 & 4 \\
\hline cleaning industry related professions & 93 & 4 \\
\hline \multicolumn{3}{|c|}{ *The groups are merged into the following equally sized broad occupational groups: } \\
\hline
\end{tabular}




\section{IZA Discussion Papers}

No Author(s)

241 W. Koeniger

242

G. Faggio

J. Konings

243

E. Brainerd

244 S. M. Fuess, Jr. M. Millea

245 F. Andersson

K. A. Konrad

246 E. Plug

W. Vijverberg

247 E. Plug

W. Vijverberg

248 P. M. Picard

E. Toulemonde

249

B. M. S. van Praag

P. Cardoso

250 T. J. Hatton

J. G. Williamson

251 R. Yemtsov

252 R. Yemtsov

253

R. Yemtsov

254 H. Gersbach

A. Schniewind

255

H. Gersbach

A. Schniewind
Titel

Area

Date

Trade, Labor Market Rigidities, and Government- 2

$01 / 01$ Financed Technological Change

Job Creation, Job Destruction and Employment 4

Growth in Transition Countries in the 90's

$01 / 01$

Economic Reform and Mortality in the Former

4

$01 / 01$

Soviet Union: A Study of the Suicide Epidemic in the 1990s

Pay and Productivity in a Corporatist Economy: $\quad 5$

$01 / 01$

Evidence from Austria

Globalization and Human Capital Formation

5

$01 / 01$

Schooling, Family Background, and Adoption:

5

Does Family Income Matter?

$01 / 01$

Schooling, Family Background, and Adoption:

5

$01 / 01$

Is it Nature or is it Nurture?

The Impact of Labor Markets on Emergence and 2

Persistence of Regional Asymmetries

"Should I Pay for You or for Myself?"

The Optimal Level and Composition of

Retirement Benefit Systems

Demographic and Economic Pressure on

Emigration out of Africa

Labor Markets, Inequality and Poverty in Georgia

$01 / 01$

Inequality and Income Distribution in Georgia

4

$01 / 01$

Living Standards and Economic Vulnerability in $\quad 4$

$01 / 01$

Turkey between 1987 and 1994

Learning of General Equilibrium Effects and the 3

Unemployment Trap

$02 / 01$

Product Market Reforms and Unemployment in 3

$02 / 01$ 
258 M. Rosholm

The Times They Are A-Changin':

02/01

K. Scott

Organizational Change and Immigrant 
273 G. Saint-Paul

274 P. J. Pedersen

N. Smith

275 G. S. Epstein

T. Lecker

276 B. Amable

D. Gatti

277 R. Winter-Ebmer

278 T. M. Andersen

279 T. M. Andersen

280 P. Apps

R. Rees

281

G. Saint-Paul

282

J. Albrecht

A. Björklund

S. Vroman

283 M. Hagedorn

A. Kaul

V. Reinthaler

284 H. Rapoport

A. Weiss

285

J. Jerger

C. Pohnke

A. Spermann

286 M. Fertig

C. M. Schmidt
Dynamic Self-Selection

Distribution and Growth in an Economy with

5

03/01

Limited Needs

Unemployment Traps: Do Financial Dis-

3

03/01

incentives Matter?

Multi-Generation Model of Immigrant Earnings: $\quad 1$

$03 / 01$

Theory and Application

The Impact of Product Market Competition on

5

$03 / 01$

Employment and Wages

Evaluating an Innovative Redundancy-Retraining 6 Project: The Austrian Steel Foundation

$03 / 01$

Welfare Policies, Labour Taxation and Inter-

2

$04 / 01$ national Integration

$04 / 01$

Product Market Integration, Wage Dispersion

2 and Unemployment

04/01

Household Savin
the Life Cycle

7

$04 / 01$

Information Technology and the Knowledge

5

04/01

Elites

Is There a Glass Ceiling in Sweden?

5

$04 / 01$

Welfare Analysis in a Schumpeterian Growth

7

$04 / 01$

Model with Capital

The Optimal Size for a Minority

$04 / 01$

Gut betreut in den Arbeitsmarkt?

5

04/01

Eine mikroökonometrische Evaluation der

Mannheimer Arbeitsvermittlungsagentur

First- and Second-Generation Migrants in Germany -What Do We Know and What Do People Think 
287 P. Guggenberger

A. Kaul

M. Kolmar

288

D. A. Cobb-Clark

289

L. Cameron

D. A. Cobb-Clark

290 D. A. Cobb-Clark

M. D. Connolly

C. Worswick

291 R. T. Riphahn

E. Wasmer

293

D. Cobb-Clark

T. F. Crossley

294 Š. Jurajda

295 F. Duffy

P. P. Walsh

296 H. S. Nielsen

M. Rosholm

N. Smith

L. Husted

297 J. C. van Ours

J. Veenman

298 P. Telhado Pereira

P. Silva Martins

G. Brunello

C. Lucifora

R. Winter-Ebmer

300 A. Stutzer

R. Lalive
Efficiency Properties of Labor Taxation in a

Getting Ahead: The Determinants of and Payoffs

5 to Internal Promotion for Young U.S. Men and Women

Old-Age Support in Developing Countries: Labor Supply, Intergenerational Transfers and Living Arrangements

The Job Search and Education Investments of

04/01 Immigrant Families

05/01

Cohort Effects in the Educational Attainment of Second Generation Immigrants in Germany: An Analysis of Census Data

Between-group Competition in the Labor Market and the Rising Returns to Skill: US and France 1964-2000

Gender, Comparative Advantage and Labor Market Activity in Immigrant Families Insurance Compensation on the Labor Market Histories of Displaced Workers

Individual Pay and Outside Options:

05/01

Evidence from the Polish Labour Force Survey

Intergenerational Transmissions and the School- 1 to-Work transition of $2^{\text {nd }}$ Generation Immigrants Immigrants in The Netherlands

Returns to Education and Wage Equations

06/01

The Wage Expectations of European College

5

06/01 Students

The Role of Social Work Norms in Job Searching 5 and Subjective Well-Being 

firm Bargaining

G. Abío

E. Berenguer

J. Gil

C. Patxot Accounting Perspective on Fiscal Policy and 
315 W. H. J. Hassink R. Schettkat

316 M. Frondel C. M. Schmidt

317 R. Winkelmann

318 M. Pannenberg G. G. Wagner

319

R. Euwals

R. Winkelmann

320 R. Fahr

U. Sunde
On Price-Setting for Identical Products in Markets without Formal Trade Barriers

Rejecting Capital-Skill Complementarity at all 5 Costs

Health Care Reform and the Number of Doctor 7 Visits - An Econometric Analysis

Overtime Work, Overtime Compensation and the Distribution of Economic Well-Being: Evidence for West Germany and Great Britain

Why do Firms Train? Empirical Evidence on the First Labour Market Outcomes of Graduated Apprentices

Strategic Hiring Behavior in Empirical Matching 1 Functions 06/01

06/01 